Metodički obzori 6(2011)1

Original scientific article

UDK: 371:811.163.42'35/'36

Received: 15. 9. 2010.

\title{
MODELS OF INDIVIDUALISATION OF LOWER ELEMENTARY TEACHING
}

\author{
Zorica Kuzmanović, MSc \\ Centre „Zaštiti me", Banja Luka (Bosnia and Herzegovina) \\ e-mail: zorica.kuzmanovic@ hotmail.com \\ Aldeida Bašić, graduate educator \\ Centre „Zaštiti me", Banja Luka (Bosnia and Herzegovina) \\ e-mail: aldeida_basic@live.com
}

Every child is smart in its way

(Levine, 2003)

\section{Su $\boldsymbol{m} \boldsymbol{m} \boldsymbol{a r y}$}

It is exactly the awareness of differences between the children that makes the initial incentive of considering and of practical attempts as to how to adjust teaching to their individual capabilities. The ever increasing need to strongly individualize work with children at any level of education, that is to say, to adjust it to their personal characteristics, has become even more prominent in the last decades in the world. This is due to the tendency that respect of human rights, respect of differences between people and respect of a man, as an individual, should be considered as the most important legacies of the civilized society, in which it is inconceivable to have an educated person who cannot express himself/herself properly, either in oral or written form, or who has a scarce active vocabulary, or who does not know the basic laws of the standard literary language.

Bearing in mind that the importance of mother tongue is essential, we decided to analyze the efficiency of the model of individualization of teaching grammar and orthography.

The aim of the empirical research was to establish whether individualization of lower elementary teaching of grammar and orthography can reach significantly better educational results in terms of statistics than in the case with teaching which is not individualized, that is to say, which is traditional.

In this written work we will represent results of research which show that by individualization of lower elementary teaching of grammar and orthography can achieve significantly better educational results in terms of statistics can be achieved than in the case with teaching which is not individualized, that is to say, which is traditional.

The obtained results can represent a very significant contribution in resolving of a current and highly important issue of our contemporary education and upbringing. 
Previous considerations, presentations and interpretations may encourage further research in this field.

Key words: individualization of lower elementary teaching of grammar and orthography, models of individualization of lower elementary teaching of grammar and orthography, didactic and methodical bases of individualization of lower elementary teaching of grammar and orthography.

\section{Introduction}

The topic of this paper is a didactic-methodological foundation and model of classroom teaching individualization. Considering this topic, this work must meet the basic task of checking the efficiency of the model of individualized teaching of grammar and spelling. To achieve its efficiency and functionality, modern grammar and spelling teaching must be open to innovations. Abandoning of the traditional modes and introduction of innovative forms of grammar and spelling will make teaching more attractive and interesting. If this kind of work, allowing all students to experience success and progress in accordance with their capabilities, is enabled, we can talk about teaching that is customized to each student. In this way teaching will adapt to the deffierences occurring between pupils and eliminate the weaknesses revealed in the traditional teaching. The reform of education in our country has reinforced the tendency of individualization of teaching. In this paper special attention will be paid to the individualization of the teaching of grammar and spelling. We will present the results of a research whose aim was to determine whether individualization of the teaching of grammar and spelling in the classroom leads to significantly better results than the traditional non-individualized teaching. The results can induce teachers to create and implement a variant of the above model of individualized teaching not only when teaching grammar and spelling, but also in other subjects and areas of education.

If we are to achieve a richer culture, rich in contrasting values, we must recognize the whole gamut of human potentialities, and so weave a less arbitrary social fabric, one in which each diverse gift will find a fitting place

Margaret Mead

\section{Methods}

Many studies have unequivocally confirmed that there are obvious needs to respect individual differences in students of the same classes. Hence the need for a gradual and increasingly radical modification of the concept of educational work, from a more flexible set of school standards on attendance and curricula, to the teaching contents, requirements, procedures and steps which are, in their richness and diversity, properly and specifically tailored to each student, thus ensuring and guiding a student's 
progress. These changes do not abolish the existing organization of teaching, but lead to its upgrading and modernization in terms of improving educational effects and an essentially individualized teaching. In pedagogical literature, several studies have presented the results of studies and research of the phenomenon of individualized learning. Therefore, the subject of our research can be defined as a synthesis of theoretical studies and empirical and experimental testing.

No theoretically based didactic and methodological researches are known to us that would be related to the individualization of early schooling teaching of grammar and spelling, which in a certain meaning represents a challenge for this research. Challenge is even greater given the fact that the individualization of teaching grammar and spelling is a rather current innovation in teaching that supports the changing of the existing teaching practices, and emphasizes an individualized approach to all students to develop and strengthen the specific needs of teaching of all students in optimal conditions for their development.

Having completed the theoretical studies of individual differences of students, especially children with special needs, as well as of an assessment of the needs and possibilities of individualization of their learning, we will start developing or implementing the concept of empirical research. The basic task of our empirical research was to determine the needs and possibilities of individualization of the model primary teaching of grammar and spelling and to experimentally determine the educational effects of such models. After outlining the didactic-methodical basis of individualization of primary teaching of grammar and spelling, we defined and studied these models to develop independent learning of grammar and spelling (use of instructional sheets, individual planned teaching, teaching different levels complexity and interactive teaching different levels of complexity). The subject of our empirical research was to determine the educational effects of these models compared to traditional primary teaching of grammar and spelling. In the course of the study, we empirically verified the application of the model of individualization of primary teaching of grammar and spelling, highlighting its key educational effect: the knowledge of students that is differentiated at three levels of complexity, which sublimate the basic teaching skills and qualities:

1) basic knowledge of programme contents,

2) understanding and comprehension of the facts, and

3) discovery learning, the creative application of knowledge.

\section{The importance of research}

In conditions where the modern way of life requires the school to meet new civilization challenges, it becomes apparent that the traditional formal education curricula do not provide personal development capable to cope with the challenges of the $21^{\text {st }}$ century. Studying and testing the problem of finding the most rational approach to learning grammar and spelling, as well as models of individualized teaching of grammar and spelling that enable recognition and personal growth, is of great importance for improving the work of each teacher. This problem reflects a much 
broader situation, and as such has multiple significance. This research is carried out for scientific, social and professional reasons.

\section{The objective and tasks of the research}

The objective of this study was to identify topics of theoretical basis and to develop a model of individualization of primary teaching of grammar and spelling, and the tasks of empirical research were to determine whether individualization of primary teaching of grammar and spelling achieved significantly better results than teaching that was not individualized but traditional:

1. Check that individualization of teaching of grammar and spelling achieved significantly higher educational outcomes than the traditional, non-individualized, teaching.

2. Determine whether individualization of teaching of grammar and spelling at different levels of complexity (NRNS) achieved significantly greater success in acquiring the program content rather than teaching that is not individualized.

3. Check that individualization of teaching of grammar and spelling in interactive teaching at different levels of complexity (INRNS) achieved significantly better educational outcomes than in teaching that is not individualized, which is traditional.

\section{Research hypotheses}

Main hypothesis Individualization of primary teaching of grammar and spelling produced significantly better educational outcomes than the non-individualized, traditional, teaching.

\section{Auxiliary hypotheses}

1. We assume that the individualization of teaching of grammar and spelling will achieve significantly higher educational outcomes and success at grammar and spelling test than the traditional one that is not individualized.

2. We assume that the individualization of teaching of grammar and spelling in the teaching at different levels of complexity (NRNS) will achieve significantly greater success in acquiring the programme content (grammar and spelling test), than in nonindividualized teaching.

3. We assume that the individualization of teaching of grammar and spelling in the interactive teaching different levels of complexity (INRNS) will achieve significantly better educational outcomes at grammar and spelling test, than in non individualized teaching. 


\section{Study variable characteristics}

Any feature of a pedagogical phenomenon in which quantitative and qualitative results are observed is a variable in a teaching experiment. Pursuant to the the set goals and objectives of this experimental study, the following variables can be defined:

a) independent variable

b) dependent variable

In our study, the independent variable was the organization of individualized instruction (which is an experimental factor), whose effectiveness we wanted to examine with respect to a particular group of students. The dependent variable was the learning effects that were manifested in positive changes, the successful adoption of programme contents provided for the subject of Serbian language (grammar and spelling).

\section{Scientific - research methods, techniques and instruments}

The selection of survey research methods depends on the nature of research. Taking into account the characteristics of the study, the method of data collection, its aims and tasks, the following methods were applied:

- Method of theoretical analysis and synthesis

- Survey-research method,

- Experimental methods.

During the research, we used the following research techniques: Testing and analysis of pedagogical documentation.

\section{Employed research instruments}

We used the following instruments:

- Knowledge test of basic grammar and spelling (form A) and

- Review of basic grammar and spelling (form B).

\section{Statistical procedures and data analysis}

To carry out the statistical analysis we used statistical procedures that are most appropriate for the qualitative analysis of results and testing hypotheses, given the nature of the research problem. Applied statistical methods were:

- percents,

- t-ratio (mean differences)

- hi-square and contingency coefficient. 
By applying these statistical methods we obtained tabular and graphical overviews of the situation and facts.

\section{Population and sample of respondents}

Starting from the research objectives, we decided that our research sample would include fifth-grade students. We selected the sample from the population of elementary schools in the area of Banja Luka. The sample comprised fifth grade classes with 150 students, of which there were 3 experimental classes (about 80 students) and 3 control classes (approximately 75 students).

Data on the structure of the sample are given in the following tables.

Table: The structure of the student groups

\begin{tabular}{|l|c|c|c|}
\hline \multicolumn{1}{|c|}{ Group } & Primary School & Team & $\begin{array}{c}\text { Number of } \\
\text { students }\end{array}$ \\
\hline Experimental (E) & „Branko Radičević" & V3, V4, V5 & 80 \\
\hline Control (K) & „Ivo Andrić" & V2, V3, V4 & 79 \\
\hline
\end{tabular}

Overview of the structure of the sample groups indicates that the survey was conducted in two elementary schools. The structure of the control group consisted of 79 students from three fifth-grade classes of the "Ivo Andric" Elementary School - Banja Luka. The structure of the experimental group consisted of 80 students from three fifthgrade classes of the "Branko Radičević" Elementary School - Banja Luka.

\section{Organization and history research}

The flow of our study was as follows:

1. Reading literature that we had available and that was required to establish the methodological basis of the empirical research (Months: May, June, July);

2. Developing a detailed preparation of individualized teaching grammar and spelling (Month: August);

3. Preparing instruments for checking students' knowledge (Month: August);

4. Conducting experimental research (Months: September, October, November, December);

5. Sorting, processing, graphical representation, analysis of the obtained data and deduction (Months: January, February, March). 


\section{Conclusion}

In this paper, we focused on the individualization of grammar and spelling teaching. We conceived didactic and methodological bases of individualization of primary teaching of grammar and spelling, and, based on them, developed models of independent learning of grammar and spelling. The experimental model of educational effects of individualization of primary teaching of grammar and spelling was then compared to traditional primary teaching of grammar and spelling. After the experiment, we performed statistical analysis and interpretation of research results to obtain conclusions.

The models of learning and teaching theory and practice confirmed our every assumption. Overall results of our study confirmed all the auxiliary hypotheses, and consequently the main hypothesis that individualization of primary teaching of grammar and spelling would achieve significantly better educational outcomes than traditional instruction was also confirmed.

Understanding of teaching as an important and serious activity, its establishment in respect of individual differences between students, its being founded on modern, more independent learning and innovative models of teaching and learning, are a guarantee for positive changes and a real improvement of teaching.

We hope that this paper will represent a significant contribution to solving an extremely actual and important question of our modern education. The previous discussion, presentation and interpretation may encourage further research in this area, such as:

1) examining the educational effects of models of primary teaching of grammar and spelling that have not been comprised by this study,

2) examining the educational effects of individualization of primary teaching of grammar and spelling, not only in pair but in other forms of interaction, and

3) examining the educational effects of individualization of primary teaching of grammar and spelling, in other grades (II, III, IV).

Bearing in mind the fact that the organization of individualization produces a positive influence on the development and training of students, enhances socialization and develops empathy and creative processing of information, we hope that this modest research would contribute to the development of didactic and methodological theory and practice, especially in primary teaching of grammar and spelling. Every child is smart in its own original way (Levine, 2003). It is up to us to discover their intelligence and bring it to light.

\section{Bibliography}

1. Bandjur, V. i Potkonjak, N. (1996). Pedagoška istraživanja u školi. Beograd: Učiteljski fakultet, CURS. 
2. Branković, D. (1999). Metodološki postupci konstrukcije testa znanja. Naša škola br.3-4.

3. Camoy, M. (1996). Technological Change and Education, in Tuijnman, A., Ed. International Encyclopedia of Adult Education and Training. Oxford: Pergamon Press Elsevier Science.

4. Delors, J. i suradnici (1998). Učenje-blago u nama. Zagreb: Educa.

5. Dixon, N. (1994). The organization Learning Cycle. How we can learn collactivelly. London: McGrew-Hill.

6. Dotran, R. (1962). Individualizovana nastava. Sarajevo: Svjetlost.

7. Đorđević, M. (1985). Individualizacija vaspitno-obrazovnog rada u školi. Beograd: IGRO, Nova prosvjeta.

8. Đukić, M. (2003). Didaktičke inovacije kao izazov i izbor. Novi Sad: Savez pedagoških društava Vojvodine. Macmilan.

9. Howes,V.M.(ed). (1970). Individualization of instructon: A teaching strategy. New York:

10. Ilić, M. (1983). Individualizovani rad na književnom tekstu i brzina čitanja. Naša škola br. 9-10, str. 606-615.

11. Ilić, M. (1998). Nastava različitih nivoa složenosti. Beograd: Učiteljski fakultet.

12. Ilić, M. (1999b). Interaktivna nastava različitih nivoa složenosti. U knjizi: Interaktivno učenje (str. 77-108). Banja Luka: Ministarstvo prosvjete Republike Srpske i UNICEF Kancelarija u Banja Luci. fakultet.

13. Ilić, M. (2000). Metodika nastave početnog čitanja i pisanja. Banja Luka: Filozofski

14. Kyriacou, Ch. (2001). Temeljna nastavna umijeća. Zagreb: Educa.

15. Lekić, Đ. (1997). Metodika razredne nastave. Beograd: Prosvetni pregled.

16. Lerner, A. J. (1975). Principi kibernetike. Beograd: ISC.

17. Livajn, M. (2003). Svako dijete je pametno na svoj način. Beograd: Moć knjige.

18. Mandić, P. (2004). Metodologija naučnog rada. Banja Luka: Akademija nauke i umjetnosti Republike Srpske.

19. Markovac, J. (1970). Nastava i individualne razlike učenika. Zagreb: Školska knjiga.

20. Marsh, C. (1994). Kurikulum. Zagreb: Educa.

21. Mužić, V. (2000). Uvod u metodologiju istraživanja odgoja i obrazovanja. Zagreb: Educa.

22. Nastavni plan i program za osnovnu školu (2002). Srpsko Sarajevo: Zavod za udžbenike i nastavna sredstva.

23. Paivi, A. (2002). Theoris of curriculum and teaching. (Plan for lecturing).

24. Stevanović, M. (1982). Metodički priručnik za nastavu srpskohrvatskog jezika i književnosti u osnovnoj školi. Gornji Milanovac: Dječije novine.

25. Stojanović, S. (2007). Obrazovno-vaspitni efekti responsibilne i interaktvne razredne nastave. Neobjavljen. Banja Luka: Filozofski fakultet.

26. Suzić, N. (2005). Pedagogija za XXI vijek. Banja Luka: TT-Centar.

27. Šimić, M. i Prica, A. (1966). Nastava gramatike u osnovnoj školi. Beograd: Vuk Karadžić.

28. Težak, S. (1980). Gramatika u osnovnoj školi. Zagreb: Školska knjiga. 
Metodički obzori 6(2011)1

Izvorni znanstveni rad

UDK: 371:811.163.42'35/'36

Primljeno: 15. 9. 2010.

\section{MODELI INDIVIDUALIZACIJE RAZREDNE NASTAVE}

Mr. sc. Zorica Kuzmanović,

Centar „Zaštiti me", Banja Luka (Bosnia and Herzegovina)

e-mail: zorica.kuzmanovic@ @otmail.com

Aldeida Bašić, diplomirani edukator i rehabilitator

Centar ,Zaštiti me", Banja Luka (Bosnia and Herzegovina)

e-mail: aldeida_basic@live.com

\section{Sažetak}

Svijest o razlikama među djecom jesu polazni poticaj razmišljanja i praktičnih pokušaja o tome kako da se nastava prilagodi njihovim individualnim sposobnostima. Sve izraženija potreba da se rad sa djecom na bilo kom nivou školovanja u što većem obimu individualizira, odnosno, prilagodi njihovim osobinama ličnosti, posljednjih decenija je u svijetu još naglašenija, zbog tendencije da se poštovanje ljudskih prava, uvažavanje razlika među ljudima i poštovanje čovjeka, kao posebnog bića, smatraju najvažnijim tekovinama civiliziranog društva, u kojem se ne može zamisliti obrazovan čovjek koji se jezično usmeno i pismeno pogrešno izražava, koji ima siromašan aktivni rječnik, koji ne poznaje osnovne zakonitosti našeg standardnog književnog jezika. Imajući u vidu da je značaj materinjeg jezika fundamentalan, opredijelili smo se da ispitamo efikasnost modela individualizacije nastave gramatike i pravopisa.

Cilj empirijskog istraživanja je utvrditi da li se individualizacijom razredne nastave gramatike i pravopisa postižu statistički značajno bolji rezultati nego nastavom koja nije individualizirana, tj. koja je tradicionalna.

U ovom radu prikazat ćemo rezultate istraživanja iz kojih se vidi da se individualizacijom razredne nastave gramatike i pravopisa postižu statistički značajno bolji obrazovni učinci nego nastavom koja nije individualizirana, tj. koja je tradicionalna. Dobiveni rezultati mogu predstavljati izuzetno značajan prilog rješavanju jednog nadasve aktualnog i važnog pitanja našeg suvremenog obrazovanja i odgajanja. Prethodna razmatranja, prezentacije i interpretacije mogu poticati daljnja istraživanja u ovoj oblasti.

Ključne riječi: individualizacija razredne nastave gramatike $i$ pravopis, modeli individualizacije razredne nastave gramatike i pravopisa, didaktičko-metodičke osnove individualizacije razredne nastave gramatike i pravopisa. 